KOŚCIÓŁ I PRAWO 8(21) 2019, nr 2, s. 119-129

DOI: http://dx.doi.org/10.18290/kip.2019.8.2-7

\title{
Miroslav Dovda
}

\section{LITURGIA SAKRAMENTU MAŁŻEŃSTWA W REALIACH LITEWSKICH W DIECEZJI WIŁKAWISZSKIEJ}

\begin{abstract}
Jan Paweł II w Kodeksie Prawa Kanonicznego z 1983 r. ${ }^{1}$ podaje opisową definicję małżeństwa, zgodnie z którą "małżeństwo to przymierze, przez które mężczyzna i kobieta tworzą ze sobą wspólnotę całego życia, skierowaną ze swej natury do dobra małżonków oraz do zrodzenia i wychowania potomstwa" (kan. 1055 § 1). To przymierze między mężczyzną a kobietą nie jest jedynie przedmiotem układu prawnego, jakiegoś kontraktu. W Kościele katolickim zostało bowiem podniesione do godności sakramentu ${ }^{2}$. Kodeksowe określenie małżeństwa, które jest zgodne z nauczaniem Vaticanum I ${ }^{3}$, stosuje pojęcie „przymierze”. Również Katechizm Kościoła
\end{abstract}

Ks. DR Miroslav DovdA - wykładowca w Wyższym Seminarium Duchownym w Kownie; adres do korespondencji: Vienuolyno 2a, Miroslavas, Litwa; e-mail: miroslav@autograf.pl; https://orcid.org/0000-0002-5495-098Xo

${ }^{1}$ Codex Iuris Canonici auctoritate Ioannis Pauli PP. II promulgatus (25.01.1983), AAS 75 (1983), pars II, s. 1-317; tekst polski w: Kodeks Prawa Kanonicznego, przekład polski zatwierdzony przez Konferencję Episkopatu, Pallottinum, Poznań 1984 [dalej cyt.: KPK/83].

2 „Przymierze małżeńskie, przez które mężczyzna i kobieta tworzą ze sobą wspólnotę całego życia, skierowaną ze swej natury na dobro małżonków oraz do zrodzenia i wychowania potomstwa, zostało między ochrzczonymi podniesione przez Chrystusa Pana do godności sakramentu". Zob. Catechismus Catholicae Ecclesiae, Libreria Editrice Vaticana, Città del Vaticano 1997; tekst polski w: Katechizm Kościoła Katolickiego, Pallottinum, Poznań 2002 [dalej cyt.: KKK], nr 1601.

${ }^{3}$ Sacrosanctum Concilium Oecumenicum Vaticanum II, Constitutio pastoralis de Ecclesia in mundo huius temporis Gaudium et spes (7.12.1965), AAS 58 (1966), 
Katolickiego odwołuje się do tej terminologii. Stwierdza bowiem: „Przymierze małżeńskie, dzięki któremu mężczyzna i kobieta tworzą ścisłą wspólnotę życia i miłości, opiera się na właściwych sobie prawach, przyznanych mu przez Stwórcę" (nr 203). Nauka Kościoła jest więc jednoznaczna: małżeństwo pochodzi z ustanowienia Bożego. Dlatego też określane jest ono mianem przymierza, w miejsce dawnego określenia umowa, przez co ustawodawca kościelny podkreśla personalistyczny charakter małżeństwa.

\section{MAŁŻEŃSTWO JAKO SAKRAMENT ŁASKI}

Małżeństwo chrześcijańskie - ze względu na to, że jest sakramentem, którego udzielaniu towarzyszy odpowiednia forma zewnętrzna - wymaga obrzędu liturgicznego. W Kościele katolickim wyraża się słuszne przekonanie, że małżonkowie jako szafarze łaski Bożej sami sobie udzielają sakramentu małżeństwa (KKK 1623). Jan Paweł II w adhortacji apostolskiej Familiaris consortio ${ }^{4}$, stwierdzając ważność przygotowania młodych ludzi do małżeństwa, odnosi je także do liturgii zaślubin: obrzęd zaślubin jako sakramentalny akt uświęcenia, włączony w liturgię będącą szczytem całej działalności Kościoła i źródłem, z którego wypływa cała jego moc uświęcająca, powinien być sam w sobie ważny, godny i owocny (FC 67).

Sobór Watykański II zalecił: „Znajdujący się w rytuale rzymskim obrzęd zawierania małżeństwa należy krytycznie rozpatrzyć i w ten sposób wzbogacić, by jaśniej oznaczał łaskę sakramentu i podkreślał obowiązki małżonków”. Stało się więc możliwe włączenie do liturgii zaślubin, zgodnie z normami Stolicy Apostolskiej, elementów właściwych danej kulturze, dzięki którym lepiej zostanie wyrażone głębokie znaczenie, ludzkie i religijne, przymierza małżeńskiego, o ile elementy te nie zawierają czegoś, co jest niestosowne dla wiary i moralności chrześcijańskiej (FC 67). Dlatego też kompetentnej władzy kościelnej została dana możliwość opra-

s. 1025-115; tekst polski w: Sobór Watykański II, Konstytucje, dekrety, deklaracje. Tekst polski. Nowe tłumaczenie, Pallottinum, Poznań 2012, s. 48-78, nr 48.

${ }^{4}$ Ioannes Paulus PP. II, Adhortatio apostolica de Familiae christianae muneribus in mundo huius temporis Familiaris consortio (22.11.1981), AAS 74 (1982), s. 81-191 [dalej cyt.: FC]; tekst polski w: „L’Osservatore Romano” (wyd. pol.) 2 (1981), s. 7-19.

5 Sacrosanctum Concilium Oecumenicum Vaticanum II, Constitutio de sacra liturgia Sacrosanctum concilium (4.12.1963), AAS 56 (1964), s. 97-138 [dalej cyt.: SC]; tekst polski w: Sobór Watykański II, Konstytucje, s. 48-78, nr 77. 
cowania własnego obrzędu, dostosowanego do zwyczajów narodowych ${ }^{6}$. Zawsze jednak należy zachować przepisy, żądać wyrażenia zgody i tę zgodę przyjąć oraz udzielić błogosławieństwa ślubnego.

\section{ZAWARCIE SAKRAMENTU MAŁŻEŃSTWA}

Ustawodawca kościelny w KPK/83 sformułował zasadę dotyczącą formy zawierania małżeństwa: „Te tylko małżeństwa są ważne, które zostają zawarte wobec asystującego miejscowego ordynariusza albo proboszcza, albo wobec kapłana lub diakona delegowanego przez jednego z nich; a także wobec dwóch świadków" (kan. 1108 § 1). Kapłan jako świadek urzędowy musi asystować przy zawieraniu małżeństwa w sposób czynny: pyta strony, czy wyrażają zgodę na zawarcie przymierza małżeńskiego, oraz w imieniu Kościoła ją przyjmuje (kan. 1108 § 2). Należy zauważyć, że formę prawną zawarcia małżeństwa przypisuje się ważności małżeństwa, natomiast forma liturgiczna wymagana jest do jego godziwości [Majer $2015,135-55]$.

Dokumenty Kościoła zalecają celebrację sakramentu małżeństwa w połączeniu ze sprawowaniem Eucharystii, ukazując, że małżeństwo należy zawierać podczas Mszy św. (SC 78; FC 57; KKK 1621). W protokole przedślubnym narzeczeni mają być pytani na początku, czy pragną przyjąć sakrament małżeństwa podczas Mszy św. bądź tylko z liturgią słowa. Na Litwie jednak ciągle odnotowywany jest znikomy procent zawarcia sakramentu małżeństwa podczas Eucharystii. Nierozerwalne przymierze małżeńskie pomiędzy mężczyzną i kobietą wyrasta i czerpie moc do trwania z przymierza, które Jezus Chrystus zawarł z Kościołem: „Między Eucharystią, która realizuje nowe i wieczne przymierze Boga ze swoim ludem, a małżeństwem objawiającym tajemnicę zaślubin Chrystusa z Kościołem istnieją głębokie powiązania" [Petryk 1998, 248].

Formularze Mszy za nowożeńców obejmują: modlitwy łącznie z prefacjami, antyfony, błogosławieństwo nowożeńców oraz błogosławieństwo na końcu Mszy św. Można również celebrować sakrament małżeństwa poza Mszą św., a proboszcz parafii, gdzie ma odbyć się obrzęd ślubu powinien

\footnotetext{
${ }^{6}$ Zob. Apeigynas: Santuokos sakramentas, Katalikų Pasaulis, Vilnius 1997, nr 39-40.
} 
zadecydować, czy podczas Mszy św. czy poza nią (SC 78)7. Liturgię małżeństwa można sprawować przez cały rok, chociaż w okresie Adwentu i Wielkiego Postu należy uwzględnić szczególny charakter tych okresów liturgicznych. Nie ma jednak zakazu udzielania małżeństw w tym czasie, wówczas przy zawieraniu sakramentu małżeństwa proboszcz ma obowiązek uświadamiania o tym narzeczonych. Jedynie w Wielki Piątek i Wielką Sobotę nie może odbyć się obrzęd sakramentu małżeństwa ${ }^{8}$.

Doniosłą rolę podczas obrzędu zawarcia sakramentu małżeństwa odgrywa liturgia słowa (FC 67). Obrzędy sakramentu małżeństwa dają do dyspozycji bogaty zestaw czytań biblijnych. Zbiór obejmuje dziewięć czytań ze Starego Testamentu, czternaście z Nowego Testamentu, siedem psalmów responsoryjnych, cztery wersety allelujastyczne oraz dziesięć czytań z Ewangelii. W procesie przygotowania do małżeństwa należy uwzględnić pracę nad treścią czytań i - jak nakazują obrzędy sakramentu małżeństwa - wspólnie z nowożeńcami uzgodnić liturgię czytań ${ }^{9}$. Przy wyborze czytań w liturgii sakramentu małżeństwa obowiązują ogólne zasady zawarte we wprowadzeniu teologiczno-pastoralnym do lekcjonarza mszalnego.

Po liturgii słowa następuje dialog celebransa $\mathrm{z}$ narzeczonymi. Jest to ostatnie skrutynium, które bada świadomość narzeczonych, a także ich dyspozycję do zawarcia małżeństwa katolickiego. Pytania dotyczą dobrowolnej zgody na małżeństwo, woli wytrwania w wierności oraz gotowości przyjęcia i wychowania potomstwa [Petryk 1998, 252]. Obrzęd zaślubin zawiera tradycyjną formułę przysięgi małżeńskiej, zawierającą wolę przyjęcia drugiej osoby za małżonka oraz ślubowanie miłości i wierności aż do śmierci. Taka przysięga wyraża teologię sakramentu małżeństwa jako nierozerwalnego przymierza.

Po złożeniu ślubnej przysięgi przez małżonków celebrans w imieniu Kościoła uroczyście potwierdza zawarcie związku małżeńskiego. Akt ten świadczy o kościelnym i społecznym charakterze małżeństwa. Bezpośrednio po jego zawarciu następuje obrzęd błogosławieństwa i nałożenia obrączek. Teksty euchologijne podczas błogosławieństwa obrączek wskazują w szczególny sposób na ich symbolikę. Wyrażają one bowiem miłość i wierność. Od tego momentu będą stale towarzyszyć małżonkom [tamże, 253]. Następnie odbywa się modlitwa powszechna, zwana modlitwą wiernych.

\footnotetext{
7 Tamże, nr 29, 36.

8 Tamże, nr 32.

9 Tamże, nr 29.
} 
Zaleca się, aby sami zaślubieni, świadkowie lub rodzice czynnie uczestniczyli we wspólnej modlitwie. Po modlitwie wiernych rozpoczyna się liturgia eucharystyczna. Jest to moment, kiedy małżonkowie mogą uzewnętrznić swój czynny udział w Eucharystii przez przyniesienie do ołtarza darów ofiarnych.

Liturgia sakramentu małżeństwa zawiera specjalne błogosławieństwo małżonków: po modlitwie Ojcze nasz celebrans zachęca zebranych do modlitwy za nowożeńców - następuje modlitwa błogosławieństwa nowożeńców $^{10}$. Zawiera ona wspomnienie genezy małżeństwa, po niej celebrans modli się o błogosławieństwo dla obojga współmałżonków. Celebracja liturgii zaślubin domaga się odpowiedniego uczestnictwa wszystkich, co powoduje, że wierni nie są widzami, lecz podmiotami działania liturgicznego. To wymaga od wszystkich wiernych, a szczególnie od nowożeńców, m.in. rozumienia wymowy znaków liturgicznych, obrzędów, modlitw i aklamacji. Każdy z uczestników powinien wypełniać powierzoną mu funkcję: obrzęd liturgiczny małżeństwa powinien włączać wspólnotę chrześcijańską przez udział wszystkich obecnych w zależności od miejsca i roli - nowożeńców, kapłana, rodziców, przyjaciół, innych wiernych, wszystkich członków zgromadzenia, które wspólnie objawia i przeżywa tajemnicę Chrystusa i Jego Kościoła (FC 67; KKK 1622). Można więc zdecydowanie potwierdzić, że obrzęd sakramentu małżeństwa jest ostatnią przedmałżeńską katechezą (FC 67).

\section{LITURGIA SAKRAMENTU MAŁŻEŃSTWA W REALIACH LITEWSKICH}

Skutki reżimu totalitarnego panującego do niedawna na Litwie spowodowały, że najczęściej sakrament małżeństwa (jak zresztą i sakrament chrztu) jest sprawowany poza Mszą św., mimo iż ponad piętnaście lat istnieją już nowe Obrzędy sakramentu małżeństwa, nadal pozostaje praktyka sakramentu małżeństwa poza Mszą św. Najczęściej nowożeńcy nie wiedzą, że jest taka możliwość zawierania sakramentu małżeństwa ${ }^{11}$ lub po prostu

${ }^{10}$ Tamże, nr 73-74.

${ }^{11}$ Wypełniając protokół przedślubny sam kapłan decyduje często na Litwie, jaka liturgia ma być, nie pytając narzeczonych o ich wolę (z 200 par narzeczonych tylko 24 były pytane, czy pragną zawrzeć sakrament podczas Eucharystii). 
nie korzystają z niej. To ukazuje ich czysto formalny pogląd na małżeństwo sakramentalne. Podaje się, iż liczba osób zawierających sakrament małżeństwa podczas Eucharystii nie sięga 4,0\%12.

Tabela 1. Liczba ślubów ze Mszą św. w wybranych parafiach z dekanatów: Mariampol, Wiłkawiszki, Szakiai oraz Aleksotas.

\begin{tabular}{|l|l|l|l|l|l|l|l|l|l|l|}
\hline Parafia & \multicolumn{2}{l}{$\begin{array}{l}\text { Ślw. Wincentego } \\
\text { à Paulo } \\
\text { (Mariampol) }\end{array}$} & $\begin{array}{l}\text { Bazylika } \\
\text { Michała } \\
\text { Archanioła } \\
\text { w Mariampolu }\end{array}$ & $\begin{array}{l}\text { Katedra } \\
\text { w } \\
\text { Wiłkawiszkach }\end{array}$ & $\begin{array}{l}\text { Jana } \\
\text { Chrzciciela } \\
\text { w Szakiai }\end{array}$ & \multicolumn{2}{l|}{$\begin{array}{l}\text { Swiętej Trójcy } \\
\text { w Garliawie }\end{array}$} \\
\hline Rok & $\begin{array}{l}\text { Liczba } \\
\text { ślubów } \\
\text { w ciągu } \\
\text { roku }\end{array}$ & $\begin{array}{l}\text { Licz- } \\
\text { ba } \\
\text { ze } \\
\text { Mszą }\end{array}$ & $\begin{array}{l}\text { Liczba } \\
\text { slubów } \\
\text { w ciągu } \\
\text { roku }\end{array}$ & $\begin{array}{l}\text { Liczba } \\
\text { ze } \\
\text { Mszą }\end{array}$ & $\begin{array}{l}\text { Liczba } \\
\text { slubów } \\
\text { w ciągu } \\
\text { roku }\end{array}$ & $\begin{array}{l}\text { Licz- } \\
\text { ba } \\
\text { ze } \\
\text { Mszą }\end{array}$ & $\begin{array}{l}\text { Liczba } \\
\text { ślubów } \\
\text { w ciągu } \\
\text { roku }\end{array}$ & $\begin{array}{l}\text { Licz- } \\
\text { ba ze } \\
\text { Mszą }\end{array}$ & $\begin{array}{l}\text { Liczba } \\
\text { ślubów } \\
\text { w ciągu } \\
\text { roku }\end{array}$ & $\begin{array}{l}\text { Liczba } \\
\text { ze } \\
\text { Mszą }\end{array}$ \\
\hline 2010 & 68 & 4 & 22 & 5 & 40 & 2 & 20 & 1 & 39 & 0 \\
\hline 2011 & 61 & 2 & 16 & 2 & 45 & 2 & 17 & 2 & 25 & 1 \\
\hline 2012 & 81 & 1 & 32 & 3 & 29 & 1 & 13 & 1 & 38 & 6 \\
\hline
\end{tabular}

Tabela 2. Liczba ślubów ze Mszą św. w wybranych parafiach z dekanatów: Alytus, Lazdijai, Prienai

\begin{tabular}{|l|l|l|l|l|l|l|l|l|l|l|}
\hline Parafia & \multicolumn{2}{|l|}{$\begin{array}{l}\text { Św. Kazimierza } \\
\text { w Alytusie }\end{array}$} & $\begin{array}{l}\text { Śliętych } \\
\text { Aniołów Stró- } \\
\text { żów w Alytusie }\end{array}$ & $\begin{array}{l}\text { NMP Wspomoży- } \\
\text { cielki Wiernych } \\
\text { w Alytusie }\end{array}$ & \multicolumn{2}{l|}{ Lazdijai } & \multicolumn{2}{l|}{ Prienai } \\
\hline Rok & $\begin{array}{l}\text { Liczba } \\
\text { ślubów } \\
\text { w ciągu } \\
\text { roku }\end{array}$ & $\begin{array}{l}\text { Liczba } \\
\text { ze } \\
\text { Mszą }\end{array}$ & $\begin{array}{l}\text { Liczba } \\
\text { ślubów } \\
\text { w ciągu } \\
\text { roku }\end{array}$ & $\begin{array}{l}\text { Liczba } \\
\text { ze } \\
\text { Mszą }\end{array}$ & $\begin{array}{l}\text { Liczba } \\
\text { ślubów } \\
\text { w ciągu } \\
\text { roku }\end{array}$ & $\begin{array}{l}\text { Liczba } \\
\text { ze } \\
\text { Mszą }\end{array}$ & $\begin{array}{l}\text { Liczba } \\
\text { ślubów } \\
\text { w ciagu } \\
\text { roku }\end{array}$ & $\begin{array}{l}\text { Licz- } \\
\text { ba } \\
\text { ze } \\
\text { Mszą }\end{array}$ & $\begin{array}{l}\text { Liczba } \\
\text { ślubów } \\
\text { w ciaggu } \\
\text { roku }\end{array}$ & $\begin{array}{l}\text { Licz- } \\
\text { ba ze } \\
\text { Mszą }\end{array}$ \\
\hline 2010 & 21 & 8 & 17 & 1 & 119 & 0 & 11 & 2 & 19 & 0 \\
\hline 2011 & 22 & 7 & 12 & 3 & 97 & 0 & 12 & 3 & 15 & 0 \\
\hline 2012 & 25 & 8 & 24 & 2 & 107 & 0 & 16 & 10 & 12 & 0 \\
\hline
\end{tabular}

Tabele 1-2 ukazują zawarcie sakramentu małżeństw w latach 20102012 w poszczególnych analizowanych parafiach oraz liczbę ślubów ze Mszą św. Z poszczególnych wybranych parafii wyróżnia się sytuacja parafii św. Kazimierza w Alytusie, w której odnotowuje się najwyższy procent ślubów z Mszą św. (33,9\%). Wzrost zawieranych małżeństw podczas

${ }^{12}$ Dane uzyskane $\mathrm{z}$ kilkudziesięciu parafii w diecezji podczas wywiadu z proboszczami poszczególnych parafii. 
Eucharystii nastąpił w parafii św. Anny w Lazdijai w ciągu ostatnich trzech lat 2010-2012, aż 38,0\%. Natomiast w parafii św. Wincentego à Paulo odnotowano tylko $3,3 \%$. Podobna sytuacja, jak podaje tabela, występuje w pozostałych analizowanych parafiach, w których rocznie odbywa się jeden bądź dwa śluby podczas sprawowania Eucharystii, w niektórych zupełnie nie ma ślubów podczas sprawowania Eucharystii, a sytuacja parafii św. Kazimierza jest pozytywnym wyjątkiem w duszpasterstwie małżeństwa i rodziny w diecezji. Należy podkreślić, że już od jej założenia i początków działalności (1992) trwało przygotowanie do małżeństwa i rodziny, i to ma zapewne wpływ na wyższą świadomość wiernych $\mathrm{w}$ tej sprawie.

W Centrum Duszpasterstwa Rodzin dekanatu alytuskiego nupturienci pytani, czy pragną zawrzeć sakrament małżeństwa podczas Eucharystii, najczęściej odpowiadali: „nie”, podając przy tym argumenty natury społecznej. Młode pary, które zgłaszają się do kancelarii z prośbą o ślub podczas Eucharystii, w większości odbyli już dłuższy, ponad trzymiesięczny kurs przygotowawczy, lub uczestniczyli w zawieraniu sakramentu małżeństwa przez przyjaciół czy bliskiej osoby podczas Mszy św. Pytani, dlaczego pragną uroczystego zawarcia sakramentu małżeństwa, najczęściej odpowiadali: „Bo to tak pięknie wyglądało”, „Była piękna i uroczysta atmosfera”. Znacznie rzadziej przytaczano argumenty pragnienia przeżycia sakramentu małżeństwa jako komunii z Bogiem.

W Kościele litewskim praktykuje się obecnie trzy wersje zawierania sakramentu małżeństwa: ślub z Mszą św., bez Mszy św., lecz z Komunią św.; bez Mszy św. i bez Komunii św. Ostatni wariant jest spotykany dosyć często, chociaż z roku na rok maleje liczba takich formalnych ślubów. Niepokojący jest fakt, że narzeczeni zajmują postawę obojętności wobec różnych form celebrowania obrzędu zaślubin. Nasuwa się wniosek, że program przygotowania przedmałżeńskiego na Litwie powinien w szerszym zakresie włączać problematykę liturgiczną. Wskazuje to na potrzebę katechezy liturgicznej, która uzdalniałaby każdego wiernego do czynnego udziału w liturgii.

Liturgia sakramentu małżeństwa wyraża się w znakach i gestach, które dla zrozumienia przez nowożeńców powinny być wcześniej wyjaśnione przez duszpasterza. Liturgia oprócz znaków i symboli ma o wiele głębsze znaczenie, w związku z tym narzeczonych zapytano o najważniejsze powo- 
dy zawarcia sakramentu małżeństwa w Kościele. Zebrane wyniki prezentuje tabela 3 .

Tabela 3. Powody zawarcia sakramentu małżeństwa w Kościele w wypowiedziach badanych narzeczonych w \%

\begin{tabular}{|c|c|c|c|c|c|}
\hline \multirow{3}{*}{$\begin{array}{c}\text { Powody zawarcia } \\
\text { sakramentu małżeństwa } \\
\text { w Kościele }\end{array}$} & \multirow[t]{2}{*}{ Ogółem } & \multicolumn{2}{|c|}{ Płeć } & \multicolumn{2}{|c|}{ Wykształcenie } \\
\hline & & Mężczyźni & Kobiety & $\begin{array}{c}\text { Średnie } \\
\text { i zawodowe }\end{array}$ & Wyższe \\
\hline & $\mathrm{N}=200$ & $\mathrm{~N}=90$ & $\mathrm{~N}=110$ & $\mathrm{~N}=116$ & $\mathrm{~N}=84$ \\
\hline Tego wymaga tradycja & $24,0 \%$ & $24,7 \%$ & $23,5 \%$ & $27,6 \%$ & $19,1 \%$ \\
\hline $\begin{array}{l}\text { Ceremonia zaślubin jest } \\
\text { uroczysta }\end{array}$ & $18,5 \%$ & $18,8 \%$ & $18,2 \%$ & $19,8 \%$ & $16,7 \%$ \\
\hline $\begin{array}{l}\text { Taki związek jest } \\
\text { nierozerwalny }\end{array}$ & $36,5 \%$ & $32,9 \%$ & $40,0 \%$ & $35,3 \%$ & $39,3 \%$ \\
\hline $\begin{array}{l}\text { Dostarcza małżonkom } \\
\text { łask Bożych }\end{array}$ & $61,0 \%$ & $60,0 \%$ & $61,7 \%$ & $58,6 \%$ & $64,3 \%$ \\
\hline $\begin{array}{l}\text { Jest spełnieniem wyma- } \\
\text { gań rodziców }\end{array}$ & $1,0 \%$ & & $0,9 \%$ & & \\
\hline $\begin{array}{l}\text { Jest jednym z sakramen- } \\
\text { tów przyjmowanych po } \\
\text { chrzcie }\end{array}$ & $42,5 \%$ & $44,7 \%$ & $40,9 \%$ & $37,9 \%$ & $48,8 \%$ \\
\hline Nie mam zdania & $1,0 \%$ & $2,4 \%$ & & $1,7 \%$ & \\
\hline
\end{tabular}

Tabela 3 informuje, że według narzeczonych zawarcie sakramentu małżeństwa w Kościele pomnaża obfitość łask Bożych (61,0\%). Taki wysoki wskaźnik charakterystyczny jest dlatego, że młodzi już na początku kursu przedmałżeńskiego dowiadują się o tym, co daje przyjęcie tego sakramentu w Kościele. Nieznacznie wyższy wskaźnik osiągnęły osoby z wyższym wykształceniem $(64,3 \%)$ aniżeli $\mathrm{z}$ wykształceniem średnim lub zawodowym $(58,6 \%)$. Wypowiedzi mężczyzn i kobiet w zasadzie się nie różnią.

Jednocześnie dość duża liczba narzeczonych na zadane pytanie odpowiada, że powodem zawarcia sakramentu małżeństwa jest, iż jest on jednym $\mathrm{z}$ sakramentów przyjmowanych po chrzcie $(42,5 \%)$. Bardziej to podkreślają mężczyźni $(44,7 \%)$ niż kobiety $(40,9 \%)$, a także osoby z wykształceniem wyższym $(48,8 \%)$ niż z wykształceniem średnim lub zawodowym $(37,9 \%)$. Na trzecim miejscu narzeczeni podkreślają, że taki związek jest nierozerwalny $(36,5 \%)$. Tu także nieznacznie przeważają kobiety nad 
mężczyznami oraz respondenci $\mathrm{z}$ wyższym wykształceniem nad osobami z wykształceniem średnim i zawodowym. Na czwartym miejscu uplasował się wymóg tradycji $(24,0 \%)$. Tutaj wyższy wskaźnik osiągnęły osoby z wykształceniem średnim i zawodowym $(27,6 \%)$ niż z wykształceniem wyższym $(19,1 \%)$. Wśród powodów zawarcia sakramentu małżeństwa narzeczeni wymieniają uroczystą ceremonię zaślubin $(18,5 \%)$. Tylko $1,0 \%$ respondentów, kobiety, opowiedziały się, że zawarcie sakramentu małżeństwa ,jest spełnieniem wymogów rodziców”. „Nie mam zdania” wypowiedzieli tylko mężczyźni $(2,4 \%)$. Te same badania wykazały, że około $40,0 \%$ badanych narzeczonych wykazuje ogromny deficyt wiedzy i zrozumienia teologicznego wymiaru małżeństwa sakramentalnego. Ocena danej sytuacji ukazuje istniejące braki w duszpasterstwie rodzin w diecezji wiłkawiszskiej.

Jak ukazują tabele 1 i 2 obrzędy sakramentu małżeństwa na Litwie w diecezji wiłkawiszskiej najczęściej odbywają się poza Mszą św. Przyczyną zaistniałej sytuacji jest brak chęci i wiedzy ze strony narzeczonych oraz brak zaangażowania duszpasterzy na polu duszpasterstwa rodzin. $\mathrm{W}$ diecezji wiłkawiszskiej, jak i na całej Litwie, kiedy liczba zawieranych małżeństw spada, zadaniem duszpasterzy jest należyte wprowadzanie narzeczonych w liturgię sakramentu małżeństwa, aby przez nią doprowadzić ich do jedności z Bogiem.

\section{PODSUMOWANIE}

Jak wynika z badań około połowy narzeczonych w latach 1991-2012 przyjmowało sakrament małżeństwa nie posiadając wszystkich sakramentów wtajemniczenia chrześcijańskiego, przeważnie bez sakramentu bierzmowania. Rokiem przełomowym na Litwie jest rok 2016, w którym to biskupi podkreślili ważność i znaczenie tego sakramentu dla narzeczonych ${ }^{13}$, poprzez wydanie instrukcji Konferencji Episkopatu Litwy.

Natomiast od 2019 r. z postanowienia Konferencji Episkopatu Litwy wszyscy narzeczeni powinni najpierw przejść formację wtajemniczenia chrześcijańskiego i dopiero potem przyjąć sakrament małżeństwa (kan.

${ }^{13}$ Lietuvos Vyskupu Konferencija, Instrukcija dèl santuokos iregistravimo parapijos santuoku knygoje ir civilines metrikacijos istaigoje bei dèl pasirengimo Santuokos sakramentui programos igyvendinimo (2016 m. rugsejo $20 \mathrm{~d}$. redakcija), https://vk. lcn.lt/doc/2016-09-20-redakcija_lvk-instrukcija-del-santuoku.pdf [dostęp: 3.11.2019]. 
$1065 \mathrm{KPK} / 83)$. Nieposiadający sakramentu bierzmowania, zgodnie z kan. $1065 \S 1$ nie mogą przyjąć sakramentu małżeństwa bez zgody biskupa diecezjalnego, w której to planują go przyjąć. Nowa zmiana oraz wymóg przygotowania się do sakramentu wydłużony od 3 do 5 miesięcy przynosi pozytywne owoce. Proboszcz parafii, gdzie odbył się ślub powinien w ciągu 10 dni kalendarzowych zarejestrować małżeństwo w urzędzie stanu cywilnego. Jedynie małżeństwo mieszane z osobą pochodzącą z innego kraju według wytycznych Konferencji Episkopatu Litwy powinno najpierw zarejestrować związek małżeński w urzędzie stanu cywilnego i dopiero potem mogą odbyć się obrzędy małżeńskie w Kościele.

Kolejnym zadaniem duszpasterzy jest dążenie do tego, aby nie pozostawić młodych małżeństw na marginesie życia eklezjalnego, ale włączać ich w aktywne życie parafii. Nowością może być obchodzenie rocznicy ślubów, chrztu ich dzieci, spotkań tematycznych, aktualnych dla młodych ludzi tworzących związek małżeński.

\title{
PIŚMIENNICTWO
}

Majer, Piotr. 2015. „Znaczenie kanonicznej formy zawarcia małżeństwa.” Annales Canonici 11:135-55.

Petryk, Piotr. 1998. Ku wspólnocie życia i miłości. Lublin: Redakcja Wydawnictw KUL.

\author{
Liturgia sakramentu małżeństwa w realiach litewskich \\ w diecezji Wiłkawiszskiej
}

\section{Streszczenie}

Przymierze między mężczyzną a kobietą nie jest jedynie przedmiotem układu prawnego lub jakiegoś kontraktu. W Kościele katolickim zostało bowiem podniesione do godności sakramentu. Nauka Kościoła jest więc jednoznaczna: małżeństwo pochodzi z ustanowienia Bożego. Dlatego też określane jest ono mianem przymierza, w miejsce dawnego określenia umowa. Ze względu na to, że jest sakramentem, którego udzielaniu towarzyszy odpowiednia forma zewnętrzna - wymaga obrzędu liturgicznego. Dlatego też ustawodawca kościelny sformułował zasadę dotyczącą formy zawierania małżeństwa. Opierając się na badaniach socjologiczno-pastoralnych autora, ukazana została strona praktyczna zawarcia małżeństwa w diecezji Wiłkawiszskiej na Litwie po odzyskaniu niepodległości od 1991 r. do 2012 r., a także zmiany zachodzące w latach późniejszych.

Słowa kluczowe: rodzina; małżeństwo; prawo kanoniczne; liturgia sakramentu 


\section{Liturgy of the Sacrament of Marriage} in Lithuania in Wiłkawiszska Diocese

\section{Summary}

The matrimonial covenant by which a man and a woman establish between themselves a partnership of the whole of life is not a legal arrangement. In the Catholic Church it has been raised to the dignity of a sacrament between the baptized. The teaching of the Church is unambiguous that marriage is a divine institution. It is therefore referred to as 'covenant' instead of the former 'contract'. This is a sacrament, which to assist at marriage must be an appropriate external form - requires a liturgical rite. Therefore, the ecclesiastical legislator formulated a rule regarding the form of the celebration of marriage. Based on the author's sociological and pastoral research, the study explores the practical side of celebration of marriage in Wiłkawiszska Diocese.

Key words: family; marriage; canon law; liturgy of the sacrament

Information about Author: Rev. Miroslav DovdA, PH.D. - lecturer in Higher Theological Seminary in Kaunas; Vienuolyno 2a, Miroslavas, Lithuania; e-mail: miroslav@autograf.pl; https://orcid.org/0000-0002-5495-098Xo 